\title{
Comparative Analysis of Palygorskite Samples From Different Occurrences in Guadalupe (Piauí, Brazil)
}

Tainara Cristina de Assis'1,2, *, Marcelle Cerqueda1,3, Cristiane Gimenes Souza², Tammy Caroline Jesus², Giullia Bertrand Marçano ${ }^{1,2}$, Karla Mayara Arguelles Simões ${ }^{1,2}$, Patrícia Viana Rodrigues ${ }^{1,2}$, Rayssa Paula Paz Furlanetto 1,2, Nathalia Oliveira Almeida dos Anjos 1,2, Luana Caroline da Silveira Nascimento ${ }^{1,4}$, Bruna de Lemos Novo ${ }^{1,2}$, Fernanda Arruda Nogueira Gomes da Silva², Fernanda Veronesi Marinho Pontes², Luciana Spinelli2, Lídia Yokoyama², Carla Napoli Barbato ${ }^{5}$, Victor Matheus Joaquim Salgado Campos 1,2 , Viviane Gomes Teixeira², Francisco Manoel dos Santos Garrido², Luiz Carlos Bertolino ${ }^{1,3}$

Assis TC (D) https://orcid.org/0000-0002-1095-2713 Cerqueda M D https://orcid.org/0000-0002-4979-0678 Souza CG (D) https://orcid.org/0000-0002-9642-9770 Jesus TC (D) https://orcid.org/0000-0002-8325-6022 Marçano GB (D) https: / / orcid.org/0000-0001-8358-2429 Arguelles KMS (D) https: / / orcid.org/0000-0002-4144-9029 Rodrigues PV (D) https://orcid.org/000000032882088X Furlanetto RPP (D) https: / / orcid.org/0000-0002-1302-8841 Anjos NOA (D) https://orcid.org/0000-0001-6760-0412 Nascimento LCS (D https:/ / orcid.org/0000-0002-1481-1969
Novo BL (iD https://orcid.org/0000-0002-5889-8082 Silva FANG (D) https://orcid.org/0000-0001-8398-9974 Pontes FVM (D) https://orcid.org/0000-0003-4373-5851 Spinelli L (D) https://orcid.org/0000-0001-7645-8657 Yokoyama L (D) https:/ /orcid.org/0000-0002-2317-4690 Barbato CN (D) https://orcid.org/0000-0002-1366-6616 Campos VMJS Dhttps://orcid.org/0000-0001-7662-1186 Teixeira VG (D) https://orcid.org/0000-0001-6699-0869 Garrido FMS (D) https://orcid.org/0000-0001-7942-7549 Bertolino LC (D) https://orcid.org/0000-0002-0908-180x

How to cite

Assis TC; Cerqueda M; Souza CG; Jesus TC; Marçano GB; Simões KMA; Rodrigues PV; Furlanetto RPP; Anjos NOA; Nascimento LCS; Novo BL; Silva FANG; Pontes FVM; Spinelli L; Yokoyama L; Barbato CN; Campos VMJS; Teixeira VG; Garrido FMS; Bertolino LC (2019) Comparative Analysis of Palygorskite Samples From Different Occurrences in Guadalupe (Piauí, Brazil). J Aerosp Technol Manag, 11, Special Edition: 62-65. https://doi.org/10.5028/jatm.etmq.53

\begin{abstract}
Palygorskite is a clay mineral that has several industrial and environmental applications. Palygorskite main deposits in Brazil are located in the municipality of Guadalupe, Piauí. A comparative study was performed with five samples of palygorskite from different locations through ore dressing and chemical and mineralogical characterization, using the XRD, XRF and methylene blue titration techniques. According to the results, there are significant differences in the samples composition. Among them, the most significant difference was the cation exchange capacity (CEC) value, which ranged from 24.0 to $41.0 \mathrm{meq} \cdot 100 \mathrm{~g}^{-1}$, followed by the content of some oxides and the crystalline phases present. Despite coming from the same region, the samples contained distinct impurities.
\end{abstract}

KEYWORDS: Palygorskite; Ore dressing; Characterization.

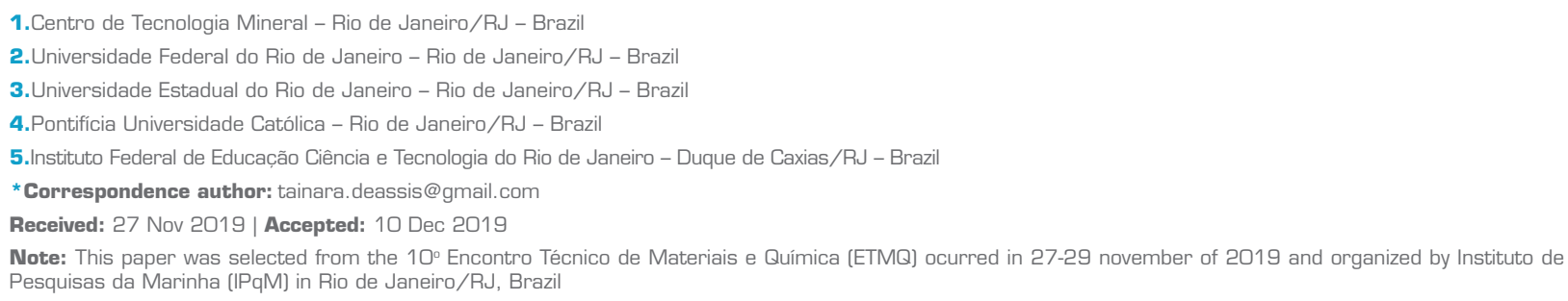




\section{INTRODUCTION}

In Brazil, palygorskite occurrences are limited to the municipality of Guadalupe, Piauí (Baltar et al. 2009) and the Alcântara region in Maranhão (Amorim and Angélica 2011). The Guadalupe region reserves have the highest potential for economic exploitation, especially from Cardoso, Mina Velha, Boa Vista and Angico mines.

Palygorskite is a clay mineral characterized by the unit cell chemical composition of $(\mathrm{Mg}, \mathrm{Al})_{5} \mathrm{Si}_{8} \mathrm{O}_{20}\left(\mathrm{OH}_{2}\left(\mathrm{OH}_{2}\right)_{4} \cdot 4 \mathrm{H}_{2} \mathrm{O}\right.$. Its three-dimensional structure is formed by two sheets of $\mathrm{SiO} 2$ tetrahedra with an octahedron formed by $\mathrm{Mg}^{2+}$ ions.

Palygorskite fine grain size $(<37 \mu \mathrm{m})$ and its fibrous nature associated with ample exchangeable cations give to it a high surface area $\left(125\right.$ to $\left.210 \mathrm{~m}^{2} \cdot \mathrm{g}^{-1}\right)$ and a cation exchange capacity (CEC) of 20 to $50 \mathrm{meq} 100 \cdot \mathrm{g}^{-1}$. Due to these properties, palygorskite has several technological applications, such as in bleaching agents, well-drilling fluids, and adsorbents of toxic metals and pesticides (Luz and Almeida 2005; Murray 2000). Recently, clay minerals such as palygorskite, that contain magnesium, aluminum and silicon in their structure, have been used to prepare cordierite ceramics, which have application in the aerospace area (Thomaidis and Kostakis 2015). For example, because of their high thermal stability, cordierite-family ceramics have been used to manufacture lightweight mirrors for cutting-edge space telescopes (Kamiya and Mizutani 2018).

The aim of this study was to analyze five palygorskite samples in pure fractions from different occurrences located in the region of Guadalupe, Piauí.

\section{MATERIALS AND METHODS}

Four palygorskite samples of approximately $10 \mathrm{~kg}$ were collected from Cardoso, Mina Velha, Boa Vista and Angico mines, as well as a sample called GDP that was provided by a local company. The sample collection area is located in the geotectonic context of the Parnaíba Basin in Guadalupe, where the main deposits of palygorskite occur in Brazil. The samples were sent to the Mineral Technology Center (CETEM-MCTIC) to perform the ore dressing and mineralogical characterization steps. To concentrate the clay minerals, the raw samples were dressed by crushing, grinding, wet screening and magnetic separation. Mineralogical characterization of fractions below $20 \mu \mathrm{m}$ was performed by X-ray diffraction (XRD) and chemical characterization (oxide content) by X-ray fluorescence spectrometry (XRF). The cation exchange capacity (CEC) was determined according to the standard methylene blue titration method based on the American Society for Testing and Materials (ASTM 2019).

\section{RESULTS AND DISCUSSION}

The XRD results (Fig. 1) indicate that the five samples have a mineralogical composition essentially consisting of palygorskite $(\mathrm{Mg}, \mathrm{Al})_{5} \mathrm{Si}_{8} \mathrm{O}_{20}(\mathrm{OH})_{2}\left(\mathrm{OH}_{2}\right)_{4} \cdot 4 \mathrm{H}_{2} \mathrm{O}$, kaolinite $\mathrm{Al}_{2} \mathrm{Si}_{2} \mathrm{O}_{5}(\mathrm{OH})_{4}$ and quartz $\mathrm{SiO}_{2}$ (Barthelmy 2014). The Angico, Mina Velha and GDP samples showed peaks related to goethite $\mathrm{FeO}(\mathrm{OH})$ (Barthelmy 2014). The Cardoso and Boa Vista samples presented low-intensity peaks attributed to montmorillonite $\mathrm{Na}_{0,2} \mathrm{Ca}_{0,1} \mathrm{Al}_{2} \mathrm{Si}_{4} \mathrm{O}_{10}(\mathrm{OH})_{2}\left(\mathrm{H}_{2} \mathrm{O}\right)_{10}$ and to diaspore $\mathrm{AlO}(\mathrm{OH})$ (Barthelmy 2014), respectively. The Angico sample showed the highest intensity of the clay mineral of interest, with the Cardoso sample presenting the lowest intensity peak. The intensity of the peaks was adjusted according to the second palygorskite peak, at $18.8^{\circ}(2 \theta)$.

The results of the chemical composition to determine oxide content (Table 1) corroborate the results obtained by XRD, since the $\mathrm{MgO}$ content in the palygorskite structure was highest for the Angico sample and lowest for the Cardoso sample. Moreover, the higher $\mathrm{Al}_{2} \mathrm{O}_{3}$ content of the Cardoso sample may be associated with the presence of montmorillonite. The GDP sample had the lowest $\mathrm{SiO}_{2}$ content, explaining the lower intensity of the quartz peak. 
Assis TC; Cerqueda M; Souza CG; Jesus TC; Marçano GB; Simões KMA; Rodrigues PV; Furlanetto RPP; Anjos NOA; Nascimento LCS; Novo BL; Silva FANG; Pontes FVM; Spinelli L; Yokoyama L; Barbato CN; Campos VMJS; Teixeira VG; Garrido FMS; Bertolino LC

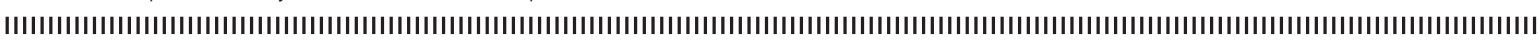

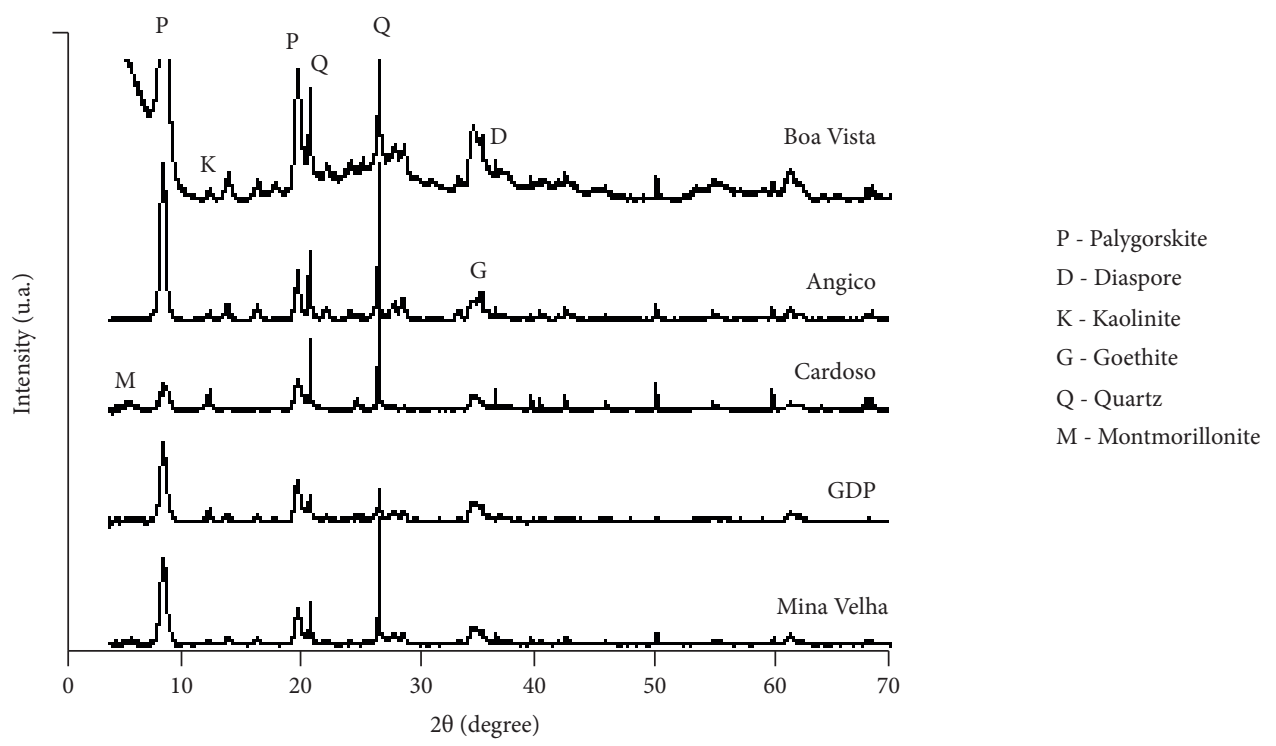

Figure 1. X-ray diffractograms, Co Ka, of palygorskite samples.

Table 1. Chemical composition of palygorskite samples.

\begin{tabular}{|c|c|c|c|c|c|c|c|c|c|}
\hline \multirow{2}{*}{ Samples $[<2 \mathrm{Om}]$} & \multicolumn{9}{|c|}{ Oxides $[\% \mathrm{w} / \mathrm{w}]$} \\
\cline { 2 - 12 } & $\mathrm{SiO}_{2}$ & $\mathrm{Al}_{2} \mathbf{O}_{3}$ & $\mathrm{Fe}_{2} \mathrm{O}_{3}$ & $\mathrm{MgO}$ & $\mathrm{K}_{2} \mathbf{O}$ & $\mathbf{C a O}$ & $\mathrm{TiO}_{2}$ & $\mathrm{Na}_{2} \mathbf{O}$ & Loss by calcination \\
\hline Boa Vista & 53.8 & 14.2 & 6.8 & 5.7 & 2.2 & 0.18 & 0.52 & 0.14 & 16.3 \\
\hline Angico & 56.5 & 12.6 & 5.5 & 6.9 & 1.4 & 0.21 & 0.7 & $<0.1$ & 15.7 \\
\hline Cardoso & 53.6 & 16.6 & 9.2 & 3.4 & 1.8 & 0.17 & 0.64 & 0.12 & 14.4 \\
\hline GDP & 49.5 & 16.4 & 7.2 & 5.4 & 2.4 & 0.33 & 0.60 & 0.12 & 18.1 \\
\hline Mina Velha & 53.5 & 13.5 & 7.0 & 5.4 & 1.9 & 0.23 & 0.55 & $<0.1$ & 17.8 \\
\hline
\end{tabular}

The CEC values obtained for the Angico, Boa Vista, Cardoso, Mina Velha and GDP samples were 24.0, 24.0, 31.0, 41.0 and $41.0 \mathrm{meq} \cdot 100 \mathrm{~g}^{-1}$, respectively, indicating that all analyzed samples were within the reference values for palygorskite (range of 20 to $50 \mathrm{meq} \cdot 100 \mathrm{~g}^{-1}$ ) (Murray 2006). The Angico and Boa Vista samples presented the lowest cation exchange capacity, a fact that may be associated with the low $\mathrm{K}_{2} \mathrm{O}$ and $\mathrm{CaO}$ contents of those samples, respectively, since these contents are related to exchangeable cations. In addition, the higher contents of these oxides are associated with higher cation exchange capacity values.

\section{CONCLUSIONS}

The palygorskite samples, despite being obtained from the same geological context, contained distinct impurities, such as montmorillonite, goethite and diaspore. Chemical composition corroborated these results. In addition, the samples presented different CEC values, but all values were between 24.0 to $41.0 \mathrm{meq} \cdot 100 \mathrm{~g}^{-1}$. Thus, the results highlight the diversity of applications of this clay mineral, such as adsorbents of herbicides and toxic metals in water bodies and of ammonium in swine wastewater. It is also used in the pharmaceutical industry for controlled drug release and delivery. This clay mineral can be used in other applications, such as oil clarification, soil correction and production of high-strength ceramics, among others. 


\section{FUNDING}

Fundação Carlos Chagas Filho de Amparo à Pesquisa do Estado do Rio de Janeiro [http://doi.org/10.13039/501100004586]

Conselho Nacional de Desenvolvimento Científico e Tecnológico [http://doi.org/10.13039/501100003593]

Grant 311627/2017-0

Coordenação de Aperfeiçoamento de Pessoal de Nível Superior [http://doi.org/10.13039/501100002322]

\section{AUTHORS’ CONTRIBUTION}

Research Idealization, Acquisition of Funding, Samples Collections, Supervision, Bertolino, LC; Conceptualization, Writing first version, All authors; Characterization and ore dressing of Palygorskite, intellectual and technical support: Simões KMA; Novo BL; Marçano GB; Bertolino, LC; Silva FANG; Teixeira VG; Garrido FMS; Yokoyama L (Cardoso sample); Assis TC; Rodrigues PV; Silva FANG; Pontes FVM; Barbato CN; Teixeira VG; Garrido FMS; Bertolino LC (Mina Velha sample); Cerqueda M; Souza CG; Jesus TC; Spinelli L; Silva FANG; Bertolino, LC (GDP sample); Furlanetto RPP; Silva FANG; Bertolino, LC (Angico sample); Nascimento LCS; Anjos NOA; Silva FANG; Bertolino, LC (Boa Vista sample); Geological support and data interpretation, Campos VMJS; Writing - Review \& Editing, Silva FANG, Novo, BL, Barbato CN.

\section{REFERENCES}

Amorim KB, Angélica RS (2011) Mineralogia e geoquímica da ocorrência de palygorskita de Alcântara, Bacia de São Luis-Grajaú, Maranhão. Cerâmica 57(344):483-490. https://doi.org/10.1590/SO366-69132011000400017

[ASTM] American Society for Testing and Materials (2019) Standard test method for methylene blue index of clay - ASTM C837-09. West Conshohocken (USA): ASTM International. https://doi.org/10.1520/C0837-09R19

Baltar CAM, Luz AB, Baltar LM, Oliveira CH, Bezerra FJ (2009) Influence of morphology and surface charge on the suitability of palygorskite as drilling fluid. Appl Clay Sci 42(3-4):597-600. https://doi.org/10.1016/j.clay.2008.04.008

Barthelmy D (2014) Mineralogy Database; [accessed 2019 Sep 16]. http://www.webmineral.com

Kamiya T, Mizutani T (2018) Development of ultra-lightweight and thermally stable cordierite ceramic mirrors. Proc SPIE 10706. Advances in Optical and Mechanical Technologies for Telescopes and Instrumentation III. https://doi.org/10.1117/12.2313073

Luz AB, Almeida SLM (2005) Argila - atapulgita e sepiolita. In: Luz AB, Lind FF, editors. Rochas e minerais industriais, usos e especificações. 1st ed. Rio de Janeiro (Brazil): CETEM. p. 201.

Murray HH (2000) Traditional and new applications for kaolin, smectite, and palygorskite: a general review. Appl Clay Sci 17(5-6):207221. https://doi.org/10.1016/S0169-1317(00)00016-8

Murray HH (2006) Applied clay mineralogy occurrences, processing and application of kaolins, bentonites, palygorskite-sepiolite, and common clays. Chapter 7, Palygorskite and Sepiolite Applications. Amsterdam (Netherlands): Elsevier Science; p. 131-140.

Thomaidis E, Kostakis G (2015) Synthesis of cordieritic materials using raw kaolin, bauxite, serpentinite/olivinite and magnesite. Ceram Int 41(8):9701-9707. https://doi.org/10.1016/j.ceramint.2015.04.039 